\title{
La investigación teatral: recepción, receptividad y fantasía del investigador
}

\section{Theatrical research: reception, receptivity and the fantasy of the researcher}

\author{
Patricio Rodríguez-Plaza \\ Pontificia Universidad Católica de Chile \\ rodriguezplaza@uc.cl
}

\section{Resumen}

Asumiendo desde una proposición heurística, la calidad de espectador del investigador teatral, el texto problematiza las ideas de recepción y receptividad estética que se experimenta en tal calidad. El punto de inicio es la invitación de Jorge Dubatti para que, haciéndose cargo de tal condición, el investigador despliegue un método de acción convivialmente situado. Principio que en el caso de este texto, es también una excusa y justificación epistemológica para desarrollar coordenadas más amplias en relación a los públicos y a los espectadores teatrales.

Palabras clave: investigador teatral, espectador, público, recepción.

\section{Abstract}

Assuming the role of the theatrical researcher as an spectator from a heuristic proposition, the piece problematizes the ideas of aesthetic reception and receptivity experienced in such capacity. The starting point is Jorge Dubatti's invitation for the researcher to develop, assuming this condition, a convivially situated course of action. A beginning that, in the case of this piece, it's also an excuse and an epistemological justification to develop wider coordinates regarding audiences and theatrical spectators.

Keywords: Theatrical Researcher, Spectator, Audience, Reception. 
El investigador teatral Jorge Dubatti, ha hecho un llamado interesante al plantear que desde la filosofía del teatro y junto con rescatar reflexivamente a esta disciplina desde su especificidad artística, tal reflexión debe focalizarse en su carácter de acontecimiento. Esto es la invocación a la realización de una actividad intelectual y experimental de un cierto modo sistemático con el propósito de contribuir, verdaderamente, al conocimiento más acabado de lo más específico y profundo de ese arte de la representación que es el teatro.

Generalmente, nos advierte el investigador argentino, lo que se estudia son los alrededores de tal acontecimiento, sus instancias previas o posteriores, pero no la disposición de lo que él ha denominado el convivio, que define la ontología de lo teatral. En un claro guiño heideggeriano, Dubatti entiende, si yo pudiera parafrasear al mismo Heidegger desde la interpretación que hago del pensamiento de Dubatti, algo así como la instauración del ser por el suceso teatral.

Desde allí que invite e incite al investigador a intervenir en la zona de experiencia o al menos que consiga materiales acerca de tal zona, ya sea por medio de lo que llama su propia experiencia convivial autoanalizada, insistiendo, y esto es lo que verdaderamente me interesa en estas notas, en que el investigador debe concebirse como un verdadero espectador-laboratorio de percepción (Dubatti, Introducción a los estilos teatrales 2012). Igualmente lo insta, desde este eje, a conseguir materias a través de los materiales relacionados con las experiencias de otros espectadores o públicos.

Este plan de acción esbozado aquí de manera gruesa significa, no solo una reflexión epistemológica para estudiar y acercarse al teatro, entendido como un hecho estético-artístico, sino una problematización respecto de una dimensión tan difícil de asir intelectualmente, pero sin la cual cualquier fenómeno cultural se vuelve un asunto verdaderamente incompleto: el público, las recepciones, las producciones simbólicas que activan, completan, y no pocas veces, determinan los asuntos artísticos. Cuestión doblemente afirmativa en el ámbito de lo teatral debido, como se sabe, al carácter transitorio y fugaz de su acontecer. En esa línea de solicitud, el investigador explicita aquello de un detenimiento respecto de lo que él llama las experiencias de los otros, que son en alguna medida la alteridad imperativa del investigador.

Sin embargo lo interesante de este llamado es la remarca que se hace del investigador como espectador para proponerle, que no sea exclusivamente un personaje que conforma esa masa que configuran los distintos públicos, sino -y esta es la lectura o el acento que yo quiero darle a tal planteamiento- la relocalización que finalmente ninguno de nosotros ha abandonado nunca.

El investigador -y por extensión la actividad investigativa en su conjunto-es, en esta línea, una persona que si bien participa desde las mediaciones y desde las perspectivas analíticas que le son propias, ante todo un espectador que activa e interviene 
en esa actividad colectiva, que en algún nivel, lo sitúa y hasta lo obliga a ser y no ser al mismo tiempo parte de un todo; de lo que podríamos llamar, un tanto abusivamente y traduciendo a Hardt y Negri, una multitud. Es decir, ubicado equidistantemente de "un sujeto social activo, que se comporta a partir de lo que las singularidades tienen en común" (Multitude 126). O también en un lugar oblicuo respecto de “... un sujeto múltiple, interiormente diferenciado, que no se construye y no reacciona a partir de un principio de identidad o de unidad y menos aún de indiferencia, sino a partir de lo que le es común" (126).

Sin embargo, o mejor, estando seguros que los investigadores participan de este fenómeno cultural que es el teatro, será necesario plantear algunas de las ideas que manejan, tratando, en lo posible, de deconstruir, tanto los supuestos sobre los cuales se afirman y afinan sus planteamientos, como las eventuales posiciones desde las cuales han realizado las perspectivas analíticas respeto del espectador. A lo cual, obviamente se le agrega una serie de puntos que inician y que esperan guiar el ejercicio que propongo. Ejercicio inicial debido a la falta de un corpus de planteamientos teóricos en nuestro medio latinoamericano; aunque en honor a la verdad, las investigaciones más acabadas que tengan presente la dimensión receptiva de la disciplina teatral, tampoco son comunes en otros ámbitos intelectuales occidentales. Así lo consignan los autores más reconocidos entre nosotros y que son, por otra parte, los mismos que serán consignados en estas notas.

Notas que se hacen cargo de una obviedad, de un lugar común, de un área cuya zona instala la dualidad recepción/receptividad de la experiencia estética, entendiendo por ello dos grandes ejes de constitución simultáneamente constantes y en movimiento: desde las tradiciones que han constituido al teatro desde los tiempos modernos y la variable desde los fenómenos y las biografías mismas que actualizan, cada vez esas convenciones. Dicho de otro modo, la experiencia con el teatro como cualquier experiencia estética o artística se mueve u oscila "entre hacer una experiencia y tener una experiencia" (Chateau, Experience esthétique 9) en donde se cruzan lo adquirido cultural, histórica y socialmente, con la dimensión subjetiva, personal e instantánea de la persona que experiencia.

Planteamiento que debería poder complementar la idea inicial, en el sentido de que si bien es cierto el teatro se juega en un nivel de acontecimiento, de corporalidad, ello no significa que tal acontecimiento no esté precedido por las categorías, las normas y las coordenadas que le dan su sustento y que permiten finalmente ese acontecer.

Es decir, que la actividad investigativa que se solicita debería concebir al teatro como un fenómeno de la cultura, armado, tanto por los ejes productivos, como por las mediaciones y evidentemente por las recepciones, cuyos ribetes mayores solo son comprendidos desde la invención moderna de lo teatral (Rodríguez-Plaza, Crítica teatral y medios 2011). Pero además, tal cual lo entiende Juan Villegas, como práctica y como discurso, toda vez que esta es también "una construcción lingüística e ideológica de un sujeto definidor” (Para la interpretación del teatro 45). Sumándole la 
expresa preocupación por el texto espectacular o teatral, ya que es allí, en ese vértice en donde se expresa la acción de lo más genuino del teatro, tal cual lo entienden hoy los estudios teatrales, al menos cuando se trata de la investigación en terreno a la manera de lo que propone Dubatti.

Lo que no significa que el texto dramático, esto es "el texto lingüístico tal y como se lee como texto escrito o se escucha pronunciado en el curso de la representación...." (Pavis, Teatro contemporáneo: imágenes y voces 88 ) no sea también parte de esta red con la cual reconocemos esta disciplina artística, que contiene una teatralidad espectacular en potencia o que puede ser leída e imaginada en término de una eventual y ulterior representación teatral.

Desde allí se ponen en juego, tanto los ajustes y conciertos explícitos y compartidos de una comunidad dada, como los imaginarios sociales, los hábitos perceptivos y evidentemente las tensiones que animan a toda sociedad, incluso en términos simbólicos. Las colectividades transan en sus mercados bursátiles hasta sus sentimientos y eso no se hace sin unos debates y hasta con oposiciones y hostilidades que nunca son meramente individuales y subjetivas. Tampoco son cuestiones estrictamente reales, con toda la estreches y artificiosidad que pueda tener esta palabra, sino que se construyen con las imaginaciones, lo inexistente, lo irreal y lo ficcional, que sería una palabra clave para referirse al teatro; al menos del teatro más convencional. Sumándole la capacidad de ficcionalización que mantiene una raíz antropológica y hasta biológica -y por lo tanto común a las culturas y sociedades- en cuyo centro se ubica la capacidad mimética, tan presente en la constitución de lo teatral. Ficcionalidad que trabaja con dispositivos, dentro de los cuales como ha señalado Jean-Marie Schaeffer, se distinguen las vías de los vectores y posturas de inmersión, entendiendo por lo primero los "fingimientos lúdicos, los ganchos miméticos que los creadores utilizan para generar un universo ficcional y que permite a los receptores reactivar miméticamente ese universo."(¿Por qué la ficción? 229) En tanto por lo segundo el mismo autor entiende "las perspectivas, las escenas de inmersión que nos asignan los vectores (...) las que determinan la aspectualidad, o la modalidad particular, bajo la que el universo se nos manifiesta, dado que entramos en él gracias a una clave de acceso específica, un vector de inmersión." (229) En el caso específico del teatro se trata de un dispositivo que "se sirve de la simulación de acontecimientos intramundanos como vector de inmersión (...) el que no es la simulación de un flujo perceptivo, sino una simulación de acontecimientos y acciones. Este vector "no está constituido por el hecho de ver y de oír los acontecimientos, sino por el hecho de asistir a esos acontecimientos" (Schaeffer 235). Así, en el teatro

el espectador percibe realmente los acontecimientos psíquicos reales y sin embargo ficcionales que se desarrollan en el espacio tridimensional real y sin embargo ficcional, y los percibe a través de la aspectualidad de sus propios actos perceptivos reales y no a través de un mimema cuasi perceptivo (al servicio de un fingimiento lúdico compartido) (236). 
En tal sentido, no hay en la percepción teatral "simulación perceptiva" y por tanto, "el salto mental que nos hace pasar de un contexto real al universo ficcional se sitúa de alguna manera a un nivel cognitivo más 'elevado' que el de los actos perceptivos (pues, contrariamente a lo que pasa con el cine, el tratamiento perceptivo no forma parte del universo ficcional" (238).

Los imaginarios, por su parte, creo deberían entenderse en términos sociales a la manera de la definición y problematización que plantea Castoriadis. Recordemos, nos dice el filósofo griego, que cuando decimos imaginario, hablamos de algo inventado, se trate de una invención absoluta o de un resbalamiento o desplazamiento de sentido donde los símbolos que se encuentran ya disponibles son investidos de otras significaciones que no son sus significaciones reconocidamente normales o canónicas. En ambos casos, continúa Castoriadis, se entiende que lo imaginario se separa de lo real, pretenda colocarse en su lugar (una mentira) o no (una novela) o evidentemente, una obra teatral. En cuanto a lo social, este lo define como quien es todos y nadie, lo que no está nunca ausente y casi nunca presente como tal. Lo social sería un no-ser más real que todo ser, en lo que nos sumergimos de par en par, pero que no podemos jamás aprehender en nadie. (L'institution imaginaire de la société 153-154). Dentro de cuyo rincón se puede ubicar lo que Bourdieu ha llamado un campo específico, que sería "como un juego, pero que no ha sido inventado por nadie, que ha emergido poco a poco de manera muy lenta" (El sentido social del gusto 38).

\section{II}

Pero también resulta interesante detenerse en algunos planteamientos de otro teórico del teatro como Marco de Marinis (2005) respecto de las maneras que se tiene de hacer teatro o contribuir con el hacer teatral, que no tiene que ver solo con el ámbito de la producción o de la recepción en el sentido que lo he venido reflexionando acá. Esto porque la idea de este profesor italiano se puede entender como un muy interesante complemento, tanto respecto del conocimiento y el estudio de la disciplina teatral, como de la situación que puede ocupar el investigador a quien muchas veces se le niega su conocimiento del teatro debido a su inexperiencia técnica en el quehacer mismo.

De Marinis se pregunta de este modo, si ¿es posible comprender una técnica teatral, y en particular la técnica del actor [por ser esta la figura capital de lo más vistoso del teatro] sin ejercerla o sin haberla ejercido directamente, es decir, sin haber tenido también, de alguna manera, una experiencia activa? Pregunta específica que está acompañada de una generalidad respecto de las artes, en tanto si ¿sería posible comprenderlas, producir un discurso o estudiarlas no siendo un productor de las mismas? Interrogaciones que lo llevan a distinguir conocimiento y comprensión del uso, es decir, entre saber y saber hacer o entre lo que llama una competencia pasiva de 
una activa. En un interesante juego de palabras, su enfoque concluye parcialmente en la distinción entre la idea de que el saber y hacer implica necesariamente el conocer, en tanto que el conocer no implica necesariamente saber y hacer.

Ahora bien las conclusiones de De Marinis, lo conducen a explicar que no existe solo una manera de experienciar y comprender lo teatral, sino que aparecen, según él, tres tipos: la del artista y actor, en cuanto competencia activa y relativamente explícita; la del espectador que él no duda en consignar de una competencia pasiva, implícita e intuitiva, y por último la experiencia y comprensión del teatrólogo o del investigador que sería una competencia también pasiva aunque colocada con fuerza sobre el eje de la explicitación.

Más adelante se detiene en algo importante para los fines que interesan acá, en el sentido de que se puede, dice él, "hacer teatro no solo produciendo espectáculos, sino también viéndolos, estudiándolos, escribiendo sobre el tema, analizando sus contextos, investigando sus procesos" (En busca del actor y del espectador 132) Asunto que puede estar fuertemente fundamentado en los hábitos, prácticas y ensayos de contemplación que el investigador vive en su papel de espectador; figura que como el mismo De Marinis subraya, puede cumplir la tarea de "dar cuenta de los otros tipos de experiencia (...) la del artista, del actor y la del espectador común”. (En busca del actor y del espectador 132) ¿Cómo se realizaría esto? pues haciendo su historia, insertándolo en un contexto más amplio, tanto sincrónica, como diacrónicamente dice De Marinis.

Si se entiende la historia, en su acepción convencional, y si se le suma a la dimensión de producción artística todo el andamiaje multidireccional que implica al actor o artista, pero que no se agota, ni mucho menos en él con mucho, sin minimizar la tarea propositiva, del investigador europeo, queda por reconocer en la idea De Marinis, una cierta mezquindad. Esto porque quien también se interese por la investigación y conocimiento del teatro puede recorrer caminos paralelos a la historia, como, por ejemplo, desde la epistemología estética u otras ciencias sociales, aunque, la teatrología, esté, por supuesto allí también considerada, en cuanto "una perspectiva capaz de evidenciar una consideración global y unitaria del hecho teatral, basada en los dos elementos primarios que lo fundan, el actor y el espectador, y más precisamente en la relación que los une, la que al fin de cuentas hoy suele llamarse simplemente la relación teatral" (Comprender el teatro 8).

En fin, lo que este investigador vuelve a subrayar en la personalidad de la propia persona que investiga analíticamente teniendo experiencia y haciendo una experiencia, repetiríamos con Dominique Chateau, cuyos derroteros pueden ser: tener experiencia de los procesos, de los resultados, experimentando -y esto es lo que habría que relevar aquí- los espectáculos en tanto espectador, y tener experiencia de la recepción, estudiando a los espectadores comunes, pero también así mismo. Lo cual, significa no solo un cambio de lugar físico o de asumir o sumar otras figuras u objetos para la investigación, sino en los fundamental, producir lo que podríamos 
llamar -siguiendo en esto al pensador Jesús Martín-Barbero- un escalofrío epistemológico (De los medios a las mediaciones 118). Escalofrío debido a la pregunta y duda metódica y casi ontológica que se hizo tal pensador latinoamericano al asistir a una función de cine en un barrio de Cali, en la descubrió que la película que a él le causaba risa y hasta burla por su sencillez y extremo sentido melodramático, era percibida por el resto de la popular audiencia con avidez, expresado ello hasta el llanto y el más profundo sentido de pertenencia y empatía vivencial. Es decir, generando aquello que el mismo Leenhardt, llamó una modalidad de lectura emocional e identificatoria, en cuya activación estética, "el lector tiende a concentrar los comentarios en los personajes más que en las situaciones" ("El saber leer" 4) o en parte lo que Umberto Eco nombró, dentro de la idea de un Lector Modelo, como un lector semántico, que como tal "desea saber cómo acaba la historia", preocupándose menos del aspecto semiótico o estético de la narración (Sobre literatura 233). Escalofrío, digo, que debería tener, al menos en nuestro medio latinoamericano, su punto más álgido en un pensamiento cogitabundo e introvertido respecto del propio investigador como fuente y crítico de la actividad espectatorial. Sin olvidar, nunca, por cierto, que él debería ser capaz, al menos hasta cierto límite, de reconocer dos cosas: que su aparataje debe saber moverse sincrónicamente con la situación de un espectador semántico y semiótico; además de saber reconocer que eventualmente las obras teatrales pueden responder a propósitos distintos, por lo que no corresponde siempre, juzgar y evaluar con los mismas herramientas conceptuales producciones que buscan objetivos diversos.

Ser crítico, en el sentido más amplio que tiene esa palabra, en tanto investigador alerta, suspicaz y hasta un tanto creativo -lo que no debe confundirse necesariamente con lo original- tiene que ver en esta línea; menos con los pasillos exteriores de las sociedades en las que habita el investigador, que con sus propios laberintos y fantasías con los que comparte un horizonte de expectativas respecto de esa misma sociedad. "El espectador, nos recuerda Pavis, es un analista [y el analista es un espectador podríamos agregar para seguir con la lógica interna de este texto] confrontado a mecanismos enigmáticos que se asimilan con el sueño y el fantasma, unos mecanismos cuyo contenido latente ha de descifrar (antes que decodificar)" (El análisis de los espectáculos 243).

\section{III}

Dicho esto, queda ahora por retomar ciertos niveles puntuales que completen operativamente lo dicho respecto del investigador en su situación de receptividad constitutiva, con la cual marca, como se ha sostenido, parte de su destino, tanto como ciudadano conocedor del teatro, como cuanto personalidad abierta a la conceptualización y tematización de experiencia de los demás. Situación, que pese a lo apuntado, no deja de constituir cuestiones obvias, pero que pese a tal obviedad y durante mucho 
tiempo, no merecieron, sino alcances menores o simplemente han sido obliterados por parte importante de los estudios literarios en donde estuvo alojado, por mucho tiempo, el saber y estudio del teatro. Así es como lo ha puesto de relieve Christopher Balme en su obra Introducción a los Estudios Teatrales. En efecto, el capítulo II, que es el dedicado a los espectadores y públicos se encuentra atravesado por la idea de la poca investigación hecha efectivamente en tal dimensión de lo teatral, pese a la aceptación generalizada, por parte de los estudios teatrales, de la "importancia de la respuesta del espectador, como un elemento crucial del teatro" (69) y en donde participan "actividades cognitivas y afectivas" (72). Es más, tal aceptación fue corroborada inicialmente por Roland Barthes, quien en términos literarios llegó a declarar la muerte del autor, ya que es el receptor y no el autor quien produce significado, no ha permitido mayores niveles de investigación en torno a la figura, justamente del receptor. Igualmente De Marinis reconoce que "a pesar de su carácter crucial [la de la relación espectáculo-público] el espectador siempre ha representado un verdadero vacio $(. .$.$) pudiéndose afirmar que nunca fue constituido seriamente como objeto$ de conocimiento (...) constituyéndose siempre en un espectador imaginario (...) de papel" (En busca del actor y del espectador 88).

Pero ¿qué es en este contexto lo obvio? El público, lo público, los públicos, y con ello las audiencias y los espectadores, dimensiones que dentro del ámbito de nuestras cuestiones culturales nacionales, como se ha adelantado, no merecen más que comentarios menores, citaciones esporádicas, conocimientos febles. Quizás la zona que más descarnada y vergonzosamente puede mostrar lo que indico, sea la crítica artística massmediática, de entre la cual la crítica teatral ocupa un lugar muy destacado (Rodríguez-Plaza, Crítica teatral y medios).

En efecto, tal crítica se ubica, quizá sin tener mucha conciencia de la invitación de Dubatti, en ese lugar de quien experiencia, pero solo desde un lugar de enunciación que anula o cree anular en su discurso su propia personalidad. Desde allí se refiere exclusivamente a los aspectos productivos de lo teatral o artístico, y quizá menos que eso, a aquellos elementos más vistosos como son los las figuras actorales o el personaje, el dramaturgo o a cierta espectacularidad de una totalidad de lo presentado. Esta es, luego la exacerbación del yo, de la individualidad, de quien se supone se ha destacado exclusivamente por su talento personal o lo más por la formación institucional que ha recibido, pero nunca, por ejemplo a la responsabilidad que en tales éxitos ha tenido el público. Este aparece como un telón de fondo, nombrado en una difusa estela de comentarios menores.

Efectivamente la crítica vive haciendo alcances al público, a sus percepciones, a sus gustos y por supuesto a sus ignorancias y equivocaciones, sin tener de él más que una imagen prefabricada y torpe. Y conste que esto no está solo referido a de informaciones estadísticas o recopilaciones cuantitativas, las que sólo muy recientemente se han instalado como referentes de cierto orden y nivel. Herramientas metodológicas, que por lo demás y pese a los inconvenientes que puedan producir tal 
cual lo ha planteado Jacques Leenhardt deberían acompañar estos trabajos de forma de lograr, por ejemplo diferenciar los textos de sus lecturas. O en el caso del teatro, de las canonizaciones críticas, históricas o teóricas marcadas por las consabidas legitimaciones institucionales, de las experiencias directas con los textos espectaculares. Entrevistas, cuestionarios y estadísticas podrían ser instrumentos válidos para acercarse a la comprensión, siempre escurridiza, de lo que las personas experimentan en sus enfrentamientos con lo artístico y teatral.

Pero esto, evidentemente no es solo una cuestión que atañe a la crítica, la que es nombrada acá, en un sentido extenso y múltiple, en tanto informaciones o comentarios más o menos elaborados y especialmente por su visibilidad social. Esta manera de asumir las cuestiones artísticas y teatrales, también involucran a buena parte de las redes que constituyen aquello que George Dickie llamó el sistema del mundo del arte (El círculo del arte 2005). Esto es una manera que enfatiza casi exclusivamente unos contenidos que serían traducidos por algunos elementos del teatro; en especial aquel trabajo de los actores quienes tendrían que atenerse a reproducir gestual y corporalmente, lo que los dramaturgos han escrito o lo que los directores les exigen.

En fin, estas notas se inscriben en una presentación de la experiencia haciendo una primera distinción entre el espectador y el público, que a decir de De Marinis responden "a los virajes teóricos decisivos que marcan y distinguen a las investigaciones en torno a la recepción teatral" (En busca del actor y del espectador 106). El primero sería una noción sociológica homogénea y abstracta, en cambio la segunda sería una entidad antropológica mucho más compleja y concreta, marcada, no solo por asuntos sociales, sino también sicológicos, culturales y biológicos.

Si pudiéramos omitir la misma diferenciación que se ha expuesto y a riesgo de que parezca arbitrario, podemos decir que llevado al terreno de la recepción, tanto el público como el espectador se mueven en unos ejes altamente complejos. Según lo ha explicado Anne Ubersfeld, uno es un eje a través del cual se sigue la acción, experimentando reacciones afectivas y la situación psicológica de expectativa personal del suspenso dramático, y el otro un eje por el cual se reciben las combinaciones de simultaneidad de lenguajes que deben ser recompuestos momento a momento en un verdadero juego de lo que ella misma llama una acrobacia percpetual. Desde allí que esta tarea y juego del espectador sea, como la misma teórica francesa lo plantea, una cuestión de deseo individual por la escenografía, la actuación de tal o cual actor que le gusta o conoce o también por la significación política e ideológica de la acción que puede incluso formar parte de un parlamento determinado.

También dichos ejes están alimentados por la denegación que implica la idea moderna de la mirada de quien sabe que lo que experimenta es y no es real, y que por tanto exige ser visualizado bajo las profundas convenciones de lo estéticamente correcto construido, entre otros términos por lo simultáneamente placentero y reflexivo y lo que Pierre Bourdieu ha llamado y recordado como estética pura. Finalmente, Ubersfeld hace hincapié en las consecuencias que el receptor suele tener sobre el 
trabajo directo de los actores, toda vez que sus silencios, respiraciones, palpitaciones y hasta sus eventuales gritos o exteriorizaciones somáticas afectan y hasta pueden determinar, positiva o negativamente el trabajo mismo del espectáculo.

Después de tal diferenciación y confluencia operativa y teórica, no queda más que advertir cuestiones que en el transcurso del último tiempo, son ya notorias:

Uno, que el público y con él las audiencias y los espectadores no es uno, sino múltiple. Lo cual nos rememora la cuestión capital de que no existe solo una manera de entender el arte, el teatro, la pintura, la escultura o cualquier otra manifestación expresiva, sino que en la medida que reconocemos las diferencias, las otredades, los compartimentos estructurales al interior de los pueblos y las sociedades debemos admitir que existen distintos grupos y con ello disímiles hábitos perceptivos, diversas maneras de goce y hasta contrapuestas formas de existencia de lo valorable y gozable estética y culturalmente.

En esta línea cabe preguntarse, luego, ¿por qué existen obras, producciones teatrales, culturales o artísticas digamos, que logran instalarse como hitos significativos dentro del espacio de nuestras sociedades y otras que terminan por producir pena, hastío, indiferencia y hasta insatisfacción social; siendo que muchas de ellas han contado en algún momento con todo tipo de oropeles y atesoramientos socialmente legítimos? Simplemente porque a unos les han parecido obras maestras, mientras que a otros les han causado la más rotunda de las despreocupaciones. Y ello no se explica -aunque podría eventualmente explicarse- sólo por factores de desconocimiento o analfabetismo en la manipulación de los códigos necesarios para su comprensión y aquilatamiento, sino simplemente a la existencia de heterogeneidades étnicas, sexuales, sociales y hasta generacionales de aquellos que juzgan. Lo cual instala al mismo tiempo la idea de que pese a las diversidades y los distintos niveles que se juegan en los gustos y actitudes frente al teatro, pues existen o pueden existir los más amplios consensos. De no ser así, no se explicarían los éxitos, las personalidades adoradas por los públicos, las modas permanentes o pasajeras respecto de cualquiera de los elementos que el teatro puede poner en el ámbito social. Asunto especialmente sensible en el caso del actor o de la actriz que si no alcanza fama o reconocimiento en su misma contemporaneidad, le resultará difícil y para algunos autores, imposible, conseguir una verdadera valía y aceptación pública.

En este punto vale la pena recordar una vez más que en nuestras sociedades latinoamericanas, el teatro ha ido convirtiéndose en un asunto menos nacional que local, menos un acontecimiento de grandes grupos o practicado en provincias, que un espectáculo para grupos localizados. Las metrópolis, siguen, en este sentido, siendo los lugares que por excelencia pueden mostrar una tradición teatral, un panorama de cierta complejidad y elaboración productiva. Esto por supuesto no significa solo una cuestión de espacios de generación de obras, sino también una mirada interesada que marca con sus derroteros, la configuración -cuando existe- de otros lugares de nuestros países. 
Estos hechos, señalados acá de manera un tanto arbitraria, deberían indicarle al investigador que sus búsquedas experienciales con el teatro, deben ceñirse, al menos parcialmente, a tener en cuenta ese hecho transcendente, del cual, por cierto, no escapa la dimensión del gusto. Dimensión, que como ha explicado Pierre Bourdieu, nos marca y nos sitúa social y culturalmente, pero también nos posibilita o nos inhibe frente a los fenómenos culturales. Es más, el mismo autor ha afirmado que "de hecho, nuestros gustos nos expresan o nos traicionan más que nuestros juicios, político por ejemplo" (Question de sociologie 156).

Dos: que este o éstos públicos son generadores de producciones simbólicas y no receptores pasivos, lectores mecánicos o manipuladores inexpertos y que por lo mismo pueden crear disfuncionalidades oblicuas con respecto a las estructuras más sólidas del poder. Le debemos a un sacerdote jesuita el habernos recordado contemporáneamente tan inequívoca cuestión. Efectivamente ha sido Michel de Certeau quien discutiendo teóricamente con el mismo Pierre Bourdieu y Michel Foucault entre otros, ha señalado y reivindicado el papel productor de lo que él en francés llamó gente ordinaria; expresión que en el contexto latinoamericano suena muy, pero muy fuerte.

Gente que en tanto habitante de la ciudad pone en marcha procedimientos multiformes, resistentes, astutos y obcecados, que sin ubicarse fuera del campo en donde se ejerce, por ejemplo la disciplina racional y utópica de la estructuración urbana plantea una producción simbólica. Producción de creación en los modos de empleo, maneras de utilización y usos y costumbres que permite y alienta el savoir-faire de la multitud; animando un área de subversión creativa, poïetica hecha de giros, capturas y distorsiones y no simplemente una práctica de consumo -frente a los mensajes industrial o profesionalmente hechos por los productores de mensajes- en el sentido restrictivo que suele tener dicha noción.

En nuestro continente han sido no pocos los que han señalado igualmente algo en el mismo sentido. Ángel Rama y su muy conocida obra La Ciudad Letrada, ha explicado que desde sus orígenes la ciudad latinoamericana fue gestando un desencuentro a la vez que

un despliegue suntuoso de un lenguaje mediante dos redes diferentes y superpuestas: la física, que el visitante común recorre hasta perderse en su multiplicidad y fragmentación, y la simbólica que la ordena e interpreta, aunque solo para aquellos espíritus afines capaces de leer como significaciones los que no son nada más que significantes sensibles para los demás, y, merced a esa lectura, reconstruir el orden (69).

Poniendo así de manifiesto que el mundo urbano hace convivir, a veces hasta en paralelo, universos en el que cada uno de ellos posee sus lógicas actuantes, sus quehaceres propios, sus deseos vertidos en estratagemas semánticas, y, evidentemente, su propias percepciones y producciones simbólicas. 
Por su parte Jesús Martín-Barbero y su cambio de dial crítico consagrado en su famoso y ya legendario libro De los medios a las mediaciones o Guillermo Sunkel y sus estudios acerca de la prensa popular, quien ha terminado por enrostrarnos algo hasta ese momento y aún hoy para muchos, desconcertante: que lo popular no se encuentra necesariamente en un periódico comunista como El Siglo, sino en uno como El Clarín o La Cuarta, produciéndonos de paso el más escalofriante de los ascos. Otro tanto ha hecho Omar Rincón al detenerse analíticamente en un producto como la telenovela, destacando que "la estética de la telenovela existe, sólo que no nos gusta; es otro gusto" (Es-téticas de telenovelas 43).

No obstante, podría parecer extraño que estas citaciones se deslicen hacia temas urbanos o hacia objetos estéticos que no son propiamente producciones teatrales, pero creo que estas aproximaciones no están lejos de lo que puede o suele ocurrir con esta disciplina artística. En su base también están las genuinas experiencias y expresiones que involucran los cuerpos, las sensaciones, el aspecto estésico y somático de la persona humana.

Igualmente se debe considerar que en el último tiempo han sido las comunicaciones y sus estudios más acuciosos y no los estudios teatrales los que en América Latina produjeron un cambio respecto de la manera en que se habían entendido las relaciones entre mensajes y recepciones. Fueron pensadores conectados con las nuevas tecnologías o simplemente con los tiempos que inauguraban esta fase de la globalización-mundo los que originaron entre nosotros las variaciones más significativas para el estudio de lo que las gentes hacían con lo que experimentaban a través de los medios. Cuestión importante, pero de donde estuvo en muchas oportunidades solo insinuado la centralidad que en ello le cabía a la corporalidad y los aspectos materiales que entran acá en juego. Es el cuerpo en sus fundamentos sensibles, cognitivos, así como las dimensiones de la materialidad y la materia lo que finalmente permite la elaboración de significados y sentidos culturales.

En tal sentido es que Karin Littau ha colocado desde la crítica textual (diferenciándola de la crítica de la lectura) la problemática de la materialidad de la lectura, en tanto esta materialidad expresada en "tipografía, tipo de edición o de artefacto manuscrito, impreso en papel o en versión electrónica” (Teorías de la lectura 50) se entremezcla con los hábitos de lectura, condicionando, no solo las maneras de leer en el sentido más físico del término, sino también los significados de una obra. "La forma afecta al sentido" (53), podría ser la frase que mejor resume la problemática asumida por Littau. Lo que a su vez está marcado por el cuerpo del lector, asunto que las teorías contemporáneas han dejado de lado, asumiendo que la lectura es exclusivamente una cuestión mental.

Todo ello, una vez más, no debe ni puede estar ausente de la investigación teatral o artística, que se establece en términos de una acción de pesquisa certera e in situ, por cuanto el cuerpo es la materia viva que experimenta con otros y consigo mismo. Si el cuerpo y la materia puede quedar en un segundo plano -teorización a la que Littau se 
revela haciendo alusión, no solo a la experimentación indisoluble entre afectos y efectos, lecturas y soportes, sino también a las teorizaciones que en otros momentos históricos no hicieron tal disociación- en el caso de la disciplina teatral tal separación resulta prácticamente inexplicable. El investigador es un ser material y en tanto tal percibe otras materias y otras corporalidades que lo prolongan, a la vez que lo identifican consigo mismo. Quizá podría asumir, como tal, la calidad de performer en cuanto "práctica, epistemología y forma de comprender (...) y en cuanto lente metodológico” (31) en la dimensión que Diana Taylor le da a tal denominación. Ello para hacer de las zonas disciplinares algo poroso y movible, pero también para asumirse en su condición, no solo de quien observa y construye algo como performance, sino también en cuanto él puede participar de una actividad que lo supone e implica.

Pero también los alcances primeros respecto a la ciudad se deben a que las actividades y por extensión las experiencias teatrales o artísticas se desenvuelven hoy en un espacio-tiempo eminentemente urbano. Espacio urbano que enclaustra, prolonga y hasta determina la recepción teatral, especialmente en términos citadinos y edificativos, en cuanto la ubicación de los cuerpos se ve literalmente fijada por el armazón arquitectónico con el cual entablan entre ellos la relación de goce o hastío; o como en el hecho que ha señalado Pavis, que "los movimientos y los comportamientos de los espectadores están determinados por ritos de interacción.” (El análisis de los espectáculos 240)

Tres: que lo público es cambiante, histórico, dialogante, móvil. Afirmación que explica casi por si sola el por qué los artistas que en un momento pueden llegar a ser altamente estimados por el tiempo o época que les toca vivir, caen unas décadas o años o siglos después en el más cruel de los olvidos. ¿Por qué, si la obra, o el nombre, o la biografía es la misma? Así es como no resulta extraño que un artista, pueda quejarse y rememorar de su poca o nula aceptación en tanto creador en otros tiempos o el no poco común ejemplo de un creador que vivió muy mal sus años de educación formal y consagrarse luego como un ser fundador y talentoso que su tiempo puede reconocer. ¿Qué ha pasado?, ¿se explica esto sólo por una maduración o crecimiento de su exclusivo talento?

Las ya clásicas tesis de Hans Robert Jauss no han perdido en este sentido vigencia, al plantear la necesidad de detenerse, entre otras cuestiones en: historiar los lectores sucesivos, reconstruir la primera lectura (la de los contemporáneos); comparar la primera lectura con la actual, ya que esta informa acerca de los problemas e interrogaciones a los que la obra respondía y de cómo fue comprendida; pero también ubicar la obra en la serialidad literaria a la cual pertenece, esto porque una obra posterior puede resolver los problemas planteados por una obra anterior, además un corte sincrónico en el desarrollo cronológico permite detectar los "tiempos fuertes" de la historia literaria y finalmente vincular la historia particular (literaria) con la historia general. Desde todo esto, tal cual lo ha sintetizado el profesor Jaime 
Blume, esta proposición de la literatura cumpliría tres funciones: destruir los tabúes morales de una época, fundar una nueva moralidad y entronizar una nueva "creación social" (La crítica literaria en el siglo xx 72).

Programa nuevamente delicado al ser llevado al terreno del teatro, por cuanto su carácter remarcadamente efímero, lo resta de tal posibilidad; al menos que se recurra a registros escritos, mecánicos, físicos o informáticos para acceder, tanto a los programas, afiches, textos dramáticos, comentarios críticos, planos, fotografías, como a grabaciones, entrevistas o cuestionarios que rodeen oblicua y multidireccionalmente lo expresado en el acto de la representación.

Cuatro: que los individuos reconocen y hacen suyo sólo aquellas obras o mensajes o producciones que logran efectivamente conectarse con sus propias matrices culturales. Matrices que en nuestros pueblos latinoamericanos transitan por el campo siempre abierto de los menjunjes, de los bricolages y en donde, como también nos lo ha observado un pensador como García Canclini, la modernidad no termina nunca de llegar, ni las tradiciones terminan nunca de irse. Afirmación que debe entenderse como un complemento paradójico, toda vez que lo expuesto hasta aquí ha apuntado a exponer las redes socio-culturales que están en juego en los asuntos artísticos y teatrales y no, por lo tanto, resumidos en el aspecto objetual o productivo. Complementario porque las producciones artísticas que efectivamente adquieren relevancia está pensadas y semióticamente expresadas por entremedio de las sentidos y los sueños de las gentes; tanto en lo más sumergido, como también en lo más rudimentario.

El investigador, colocado en el efímero tempo de lo teatral, debería estar atento a la topografía cultural más profunda, pero también al lugar para vivir, experimentar e investigar en lo más doméstico de los enlaces globales: la televisión, la radio, el consumo cultural de unos habitantes conectados, desde este rincón, al mundo, mundialmente conectado a través de las redes informáticas. En este sentido, el teatro es una condensación de los muchos lenguajes que maneja y de ahí que pueda concebirse como un lugar anacrónico que dinamiza modernidades al estar situado en medio de la vida real e imaginaria de las personas en términos siempre contemporáneos.

Cinco: que la colectividad es capaz de activamientos culturales o estéticos en el entrecruzamiento de aquello que la estética de la recepción llama el horizonte de expectativas (o código primario) y el horizonte de experiencia (o código secundario). El sentido de una obra, según esta corriente de pensamiento, ya citada, se construye siempre de nuevo, como resultado de la coincidencia de aquellos códigos, desplegando toda una batería de actividades diferentes tales como consumir, criticar, admirar, rechazar, gozar por su forma, interpretar por su contenido o suscribir una interpretación conocida o intentar una nueva.

Idea amplia y general que no debe perder nunca de vista que las producciones artísticas o culturales son entes carentes de sentido histórico o significación consis- 
tente, en cuanto las obras no hablan, no dicen nada, sino que son las percepciones humanas las que activan significaciones. Idea que a su vez debe estar acompañada del recuerdo de algo que aunque todos sepamos, suele frecuentemente olvidarse: que el arte, la cultura o cualquier manifestación significativa no es sólo un asunto de obras, producciones u objetos y menos sólo un asunto de contenidos o ideas pre-armadas sino, también de percepción. En esta línea es que resulta de interés lo planteado por Josette Féral en torno a la reflexión de que la dimensión de teatralidad; por un lado no solo está presente en el teatro, entendido como un arte, sino que tal dimensión "no tiene [obligadamente] manifestaciones físicas, no tiene propiedades cualitativas que permitirían descubrirla con seguridad. No es un dato empírico. Es, [y esto es aquí lo sobresaliente] una 'ubicación del sujeto"' (Théorie et practique du théâtre 86). "Es el resultado de una dinámica perceptiva, la de la mirada que une a un observado (sujeto u objeto) y un observador" (102).

Consignar esto significa luego, asentarse, por una parte en el aspecto de "maestro chasquilla" como se le llama en Chile a quien es capaz de realizar informalmente cualquier tipo de trabajo doméstico y que condiciona a todo artista (bricoleur lo llamó Claude Lévi-Strauss) y por otra a la idea de que la cultura contiene -en la doble acepción de recibir y detener- y es significación en la medida que existen mediaciones, redes de circulación y realidades primarias que terminan por de-terminarla.

De todas estas cuestiones y para terminar, detengámonos en este último terreno para volver a remarcar algo obvio: que todo lo relativo a los materiales, formatos, colores, soportes, espacios, lugares, tamaños - conceptos muy conocidos y practicados por cualquier productor artístico, incluido aquellos que toman la materia como un ejemplo paradójico de objetualidad negada- no son simplemente aval sino incremento de la idea, de las configuraciones estéticas que no solo instalan el ser en el mundo, como diría Heidegger respecto de la poesía, sino que permiten, en un gesto no exento de la tenaz obnubilación que produce el género humano al mismo hombre, maravillarse con el mundo.

Dicho de otro modo, los elementos palpables, prosaicos y perceptibles, especialmente en el ámbito del arte, no son meras encarnaciones de significados preconcebidos, sino que dichos principios físicos son y construyen sentido. Y ello no es para nada ajeno a los públicos, practicantes y constructores de la ciudad; menos en el caso de un emplazamiento constructivo tridimensional como una escultura, la que se instala con su peso y su forma, con su plasticidad y textura, más allá de todo miramiento exclusivamente centrado en significados o contenidos metafísicos. También y de forma evidente esto pertenece al fenómeno teatral, en tanto su disposición en el mundo es efectiva y materialmente con este mundo, mientras su disponibilidad es la de ser un hueco creativo en algún rincón de ese mismo mundo.

Por ello es que la proposición de Dubatti tiene su correlato -y sé que quizá él no estaría de acuerdo con la lectura que hago de su pensamiento- en un detenimiento muy agudo en lo material, en las configuraciones que son de algún modo la 
excusa de parte de los espectadores para proceder en su goce, aburrimiento o acción personalizada o masiva de las experiencias.

Aún las alucinaciones colectivas que desplazan a los espectadores hacia zonas de supuesta trascendencia emotiva de alta intensidad, como pueden ser los sentimientos de alcance religioso, político, ecológico o de cualquier otro tipo, no sería más que un acomodo somático entrelazado con las materias que las posibilitan. Cuestiones todas que deberían ser preocupación de un investigador que se examine examinando su sitio, y sobre todo su situación de espectador en medio de la experiencia escénica convivial. ¿Cómo no estar de acuerdo entonces, con la aseveración de Dubatti en tanto que habría mayor complementariedad entre el espectador y el investigador que entre el investigador y el artista o el técnico? De todos modos esa complicidad está a su vez marcada por una condición potencial anidada en el cuerpo del investigador, quien hace suyo -cuando la experiencia funciona positivamente- lo que experiencia, a la vez que lo que experiencia es lo que andaba buscando. Y eso es posible simplemente ¿simplemente? porque lo que percibe y construye significación en algo que ya estaba en su interior. Octavio Paz, lo ha sintetizado bellamente respecto del objeto poético al decir que cada lector busca algo en el poema. Y no es insólito que lo encuentre: Ya lo llevaba dentro.

\section{Referencias}

Balme, Christopher. Introducción a los estudios teatrales. Santiago: Apuntes Frontera Sur, 2013. Medio impreso.

Bathes, Roland. Le plaisir du texte. Paris: Seuil, 1973. Medio impreso.

Bourdieu, Pierre. El sentido social del gusto. Elementos para una sociología de la cultura, Buenos Aires: Siglo XXI, 2010. Medio impreso.

---. Question de sociologie, Paris: Minuit, 1988. Medio impreso.

Blume, Jaime. "La crítica literaria en el siglo XX". Aisthesis n 21 (1988). 55-80. Medio impreso.

Castoriadis, Cornelius. L'institution imaginaire de la société. Paris: Seuil, 1975. Medio impreso.

Chateau, Dominque. Experience esthétique. Intuition et expertise, Rennes: Presses Universitaires de Rennes, 2010. Medio impreso.

De Certeau, Michel. La invención de lo cotidiano. 1 Artes de Hacer, México: Universidad Iberoamericana. Instituto Tecnológico y de Estudios Superiores de Occidente. Centro de Estudios Mexicanos y Centroamericanos (traducción de Alejandro Pescador), 1996. Medio impreso.

De Marinis, Marco. En busca del actor y del espectador. Comprender el teatro II, Buenos Aires: Galerna, 2005. Medio impreso.

---. Comprender el teatro. Lineamientos de una nueva teatrología. Buenos Aires: Galerna, 1997. Medio impreso. 
Dickie, George. El círculo del arte. Barcelona: Paidós, 2005. Medio impreso.

Dubatti, Jorge. Introducción a los estudios teatrales. Propedéutica. Buenos Aires: Atuel, 2012. Medio impreso.

Eco. Umberto. Sobre literatura. Barcelona: RqueR, 2002. Medio impreso.

Féral, Josette Théorie et practique du théâtre. Au-delà des limites, Montpellier: Éditions l'Entretemps, 2011. Medio impreso.

García Canclini, Néstor. Culturas híbridas. Estrategias para entrar y salir de la modernidad, México: Grijalbo, 1989. Medio impreso.

Jauss, Hans Robert. Pour une esthétique de la réception, París: Gallimard, 1978. Medio impreso.

Hardt, Michael y Antonio Negri. Multitude, Paris: La Découverte, 2004. Medio impreso. Jauss Hans, Robert. Pour une esthétique de la réception. Paris: Gallimard, 1978. Medio impreso.

Leenhardt, Jacques, "El saber leer o modalidades socio-históricas de la lectura”. Criterios $\mathrm{n}^{\circ}$ 25-28, enero diciembre (1990). 54-65. Medio impreso.

Littau, Karin. Teorías de la lectura. Libros, cuerpos y bibliomanía. Buenos Aires: Manantial, 2008. Medio impreso.

Martín-Barbero, Jesús. De los medios a las mediaciones. Comunicación, cultura y hegemonía, México: Gustavo Gili, 1993. Medio impreso.

Pavis, Patrice. Teatro contemporáneo: imágenes y voces, Santiago: Lom, Universidad Arcis (traducción de Gloria María Martínez) 1998. Medio impreso.

---. El análisis de los espectáculos. Teatro, mimo, danza, cine, Barcelona: Paidós, 2000. Medio impreso.

Rama, Ángel. La ciudad letrada. Santiago de Chile: Tajamar Editores, 2004. Medio impreso.

Rincón, Omar. "Es-téticas de telenovelas”. Cátedra de Artes 2 (2006), Dirección de Postgrado, Facultad de Artes, Pontificia Universidad Católica de Chile. 43-49. Medio Impreso.

Rodríguez-Plaza, Patricio. Crítica teatral y medios: el caso Beckett y Godot, Santiago de Chile: Apuntes/Frontera Sur, 2011. Medio impreso.

Schaeffer, Jean-Marie. ¿Por qué la ficción? España: Lengua de Trapo, 2002. Medio impreso.

Sunkel, Guillermo. Razón y pasión en la prensa popular. Un estudio sobre cultura popular, cultura de masas y cultura política. Santiago: Instituto Latinoamericano de Estudios Transnacionales, 1985. Medio impreso. 